\title{
HUNTINGTON DISEASE
}

\section{DNA ANALYSIS IN BRAZLIAN POPULATION}

\author{
SALMORASKIN, NASSER ALLAN, HÉLIOAG TEIE, FRANCISCOCARDOSO, \\ MÔNICA SANTORO HADDAD, GILBERTO LEV, RAQUEL BOY, J UAN LERENA J R, \\ VANESSA SANTOS SOTOMAIOR, MÔNICA J ANEEN-DÜCK, LAURA BANNACHJ ARDIM, \\ FĹGOR. FELANDER, LUIZAUGUSTOFRANCOANDRADE
}

\begin{abstract}
Huntington disease (HD) is associated with expansions of a CAG trinucleotide repeat in the HD gene. Accurate measurement of a specific CAG repeat sequence in the HD gene in 92 Brazilian controls without HD, 44 Brazilian subjects with clinical findings suggestive of HD and 40 individuals from 6 putative HD families, showed a range from 7 to 33 repeats in normal subjects and 39 to 88 repeats in affected subjects. A trend between early age at onset of first symptoms and increasing number of repeats was seen. Major increase of repeat size through paternal inheritance than through maternal inheritance was observed. Data generated from this study may have significant implications for the etiology, knowledge of the incidence, diagnosis, prognosis, genetic counseling and treatment of HD Brazilian patients.
\end{abstract}

KEY WORDS: Huntington disease, CAG repeats, Brazil, DNA, PCR.

\section{Doença de Huntington: análise de DNA na população brasileira}

RESUMO - A doença de Huntington (DH) está associada a expansões da seqüência repetitiva de trinucleotídeos CAG no gene HD. Através de análise do número de repetições CAG em indivíduos brasileiros, amostras de 92 indivíduos-controle não afetados pela $\mathrm{DH}, 44$ pacientes com $\mathrm{DH}$ e 40 indivíduos de 6 famílias com a $\mathrm{DH}$, demonstrou-se a presença de repetições de 7 até 33 trinucleotídeos CAG nos indivíduos-controle e de 39 até 88 nos alelos mutados dos indivíduos afetados. Foi constatada relação inversa entre a idade de manifestação dos primeiros sintomas da doença e o tamanho do fragmento encontrado. Também foi observado que o número de casos em que ocorrem expansões do trinucleotídeo foi maior quando o pai transmite o alelo mutado do que quando a mãe o transmite. Os dados gerados com este estudo têm importância significativa para a compreensão da etiologia, incidência, diagnóstico, prognóstico e tratamento dos pacientes com DH na população brasileira. O conhecimento da base genética desta doença na população brasileira permitirá um aconselhamento genético mais eficiente às famílias em risco.

PALAVRAS-CHAVE: doença de Huntington, repetições CAG, Brasil, DNA, PCR.

Huntington disease (HD) is a progressive, neurodegenerative disorder that presents with motor disturbances, psychiatric symptoms, and cognitive decline ${ }^{1,2}$. The mutation associated with clinical manifestations of the disease is an unstable CAG trinucleotide expansion (runs of glutamine in the gene product) in the first exon of a novel gene (called HD gene) located on $4 \mathrm{p} 16.3^{3}$. The HD gene, which spans about 200 kilobases $^{3}$, encodes two distinct transcripts, the protein huntingtin of 10,3 and 13,6 kilobases ${ }^{4}$, but its function is still unknown. Such mechanism of mutation has been shown to cause a number of other genetic disease such as myotonic dystrophy ${ }^{5}$, dentatorubral-pallidoluysian atrophy $^{6}$, spinocerebellar ataxias ${ }^{7}$, spinal and bulbar muscular atrophy ${ }^{8}$, and fragile $\mathrm{X}$ syndrome ${ }^{9}$.

Centro de Aconselhamento e Laboratório Genetika - Curitiba, PR, Brazil. Aceite: 10-julho-2000. 
The American College of Medical Genetics/American Society of Human Genetics/Huntington Disease Genetic Testing Working Group ${ }^{10}$ divided the genotype/phenotype correlation in 4 categories for CAG-repeat lengths in the exon 1 of the HD gene: normal allele (less than 27 CAG repeats, generating a normal phenotype), intermediate allele (27-35 CAG repeats, mutable normal allele generating a normal phenotype), HD allele with reduced penetrance (36-39 CAG repeats, generating a normal or HD phenotype), and HD allele (more than 39 CAG repeats, generating a HD phenotype). Alleles sized up to $26 \mathrm{CAG}$ repeats have never been associated with a HD phenotype and have not been demonstrated to show mutability. Alleles of 27-35 CAG repeats have demonstrated meiotic instability when transmitted by a male. Allele sizes of 36-39 repeats have been associated with HD phenotype in some cases documented clinically and pathologically. However, these alleles have been reported in some clinically unaffected subjects aged $>70$ years ${ }^{11}$.

It is difficult to define the smallest size of the CAG repeat expansion, which leads to the disorder. In most studies 37 repeats where reported as the lowest CAG repeat associated with HD on European descendant. The absence of HD pathology has not been documented in any individual with a HD allele size larger than 40 repeats $^{10}$. The CAG length has a significant impact on age of onset $^{12}$, defined as the first time at which a patient had either neurological or psychiatric symptoms that represented a permanent change from the normal state. The mean age of onset is 35 to 44 years, the median survival time is 15 to 18 years and the average age at death is $54-55$ years ${ }^{1,12}$. About $10 \%$ of patients with HD have juvenile onset before age 20 years ${ }^{1}$ and $5 \%$ before 14 years old ${ }^{13}$, whereas late onset (at $>50$ years of age) occurs in $\sim 20 \%{ }^{14}$. The CAG trinucleotide expansion is unstable during transmission from parents to offspring and it has been shown that the repeat length can expand during spermatogenesis. HD anticipation (offspring having symptoms at earlier ages of onset that their affected parents) is more intense in paternal transmission, that is, offspring of affected fathers on average have both longer repeat lengths and earlier ages of onset that offspring of affected mothers ${ }^{15}$.

HD occurs with variable prevalence rates in different parts of the world with most countries having rates between 5-10 affected persons per 100,000 1,2 . In Japan and Africa however, there is remarkably, a 10 times reduced prevalence rate ${ }^{16,17}$. The lowest frequencies have been found in South African Blacks, with 0.01 affected person per 100,000, that is, 500-1,000 times lower than the worldwide prevalence, but this is probably an underestimate, because the authors used only 11 documented African cases to calculate $\mathrm{it}^{17}$. A study in blacks from North America showed a prevalence of 0.97 per 100,000 persons, about one-fifth the prevalence for Caucasoid patients with HD in the same population ${ }^{18}$. It has been showed that there is a relation between incidence of HD and the median size of normal CAG repeat in different populations. The larger the median size of normal CAG repeats, the higher is the incidence of $\mathrm{HD}^{19,20}$.

The incidence as well as the genetic basis of HD in Brazil is unknown. Therefore we decided to use direct Polimerase Chain Reaction (PCR) from whole blood to genotype three groups of individuals: a) 92 healthy subjects older than 50 years old from the normal Brazilian population with no family history of HD, b) 44 unrelated HD subjects and c) 40 persons of 6 HD families.

\section{METHOD}

Ten microliters of whole blood in EDTA were collected from 92 Brazilian normal healthy controls (being 50 Caucasoids and 42 African-Brazilians), from 44 Brazilian subjects with clinical findings suggestive of HD, and 40 individuals from $6 \mathrm{HD}$ families (Fig 1).

Neurologists, psychiatrists or both have examined the 40 individuals from the $6 \mathrm{HD}$ families and the 44 subjects with HD. Information of sex and age at onset of first symptoms were recorded for each patient.

The age at onset of first symptoms for the 44 individuals with HD was: 1 patient under 10 years, 1 patient between 11 and 20 years, 10 patients between 21 and 30 years, 17 patients between 31 and 40 years and 15 patients older than 41 years. 


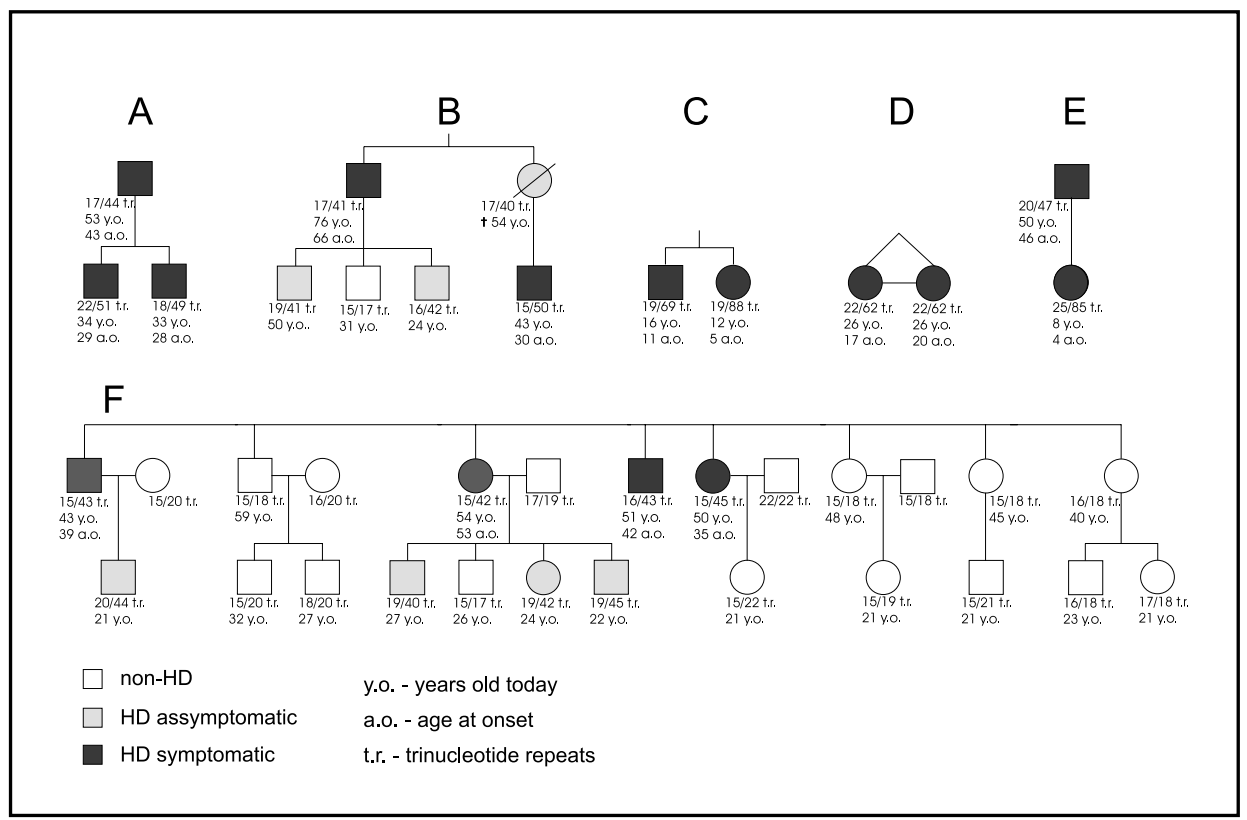

Fig 1. Families with HD.

CAG expansion was also assessed in 92 Brazilian control individuals older than 50 years old, without any signs, symptoms or family history of any neuropsychiatric disorder. They were 50 Caucasoids and 42 AfricanBrazilians, $64 \%$ male and $36 \%$ female. All of them were living in the Brazilian state of Paraná, but $60 \%$ were born in Paraná, $14 \%$ in the state of Minas Gerais, $8 \%$ in the states of Rio de Janeiro and Bahia, $4 \%$ in the state of São Paulo, and $2 \%$ in the states of Espírito Santo, Santa Catarina and Rio Grande do Sul.

Genomic DNA was extracted from leukocytes by standard procedures ${ }^{21}$. The primers used for these assay were: Hul 5'-ATGAAGGCCTTCGAGTCCCTCAAGTCCTCC-3' and HD3 5'-

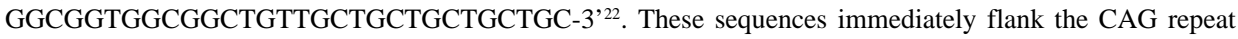
sequence and amplify specifically the CAG repeats, avoiding the downstream CCG polymorphism, and therefore avoiding errors in HD diagnostic test ${ }^{12}$. PCR was performed as described previously ${ }^{23}$. Sequencing standards were selected to allow exact determination of the size of the PCR product, including an M13 sequencing ladder and appropriate normal and abnormal controls whose CAG repeats have been sequenced independently.

Because of ethical implications of the results, all tests were done after a genetic counseling session and informed consent. The normal control group was tested without knowledge of any information that could be used to further identify the individuals, in accordance to the suggestions of the International Huntington Consortium Regulations ${ }^{10}$.

\section{RESULTS}

\section{A) Control subjects}

The normal CAG repeat spectrum in the Brazilian population sample studied, as determined by the study of 184 chromosomes from 50 Caucasoids and 42 African-Brazilians normal control subjects, ranges from 7 to 33 trinucleotides in the Caucasoid sample and from 13 to 30 in the AfricanBrazilian sample (Table 1). Repeats with 17 triplets (37\%) and 15 triplets (28.6\%) were found at a peak frequency, while the mean was 17,7 and 17,9 CAG repeats in the Caucasoid and AfricanBrazilian samples respectively, (Fig 2).

A total of 8 persons with intermediate alleles (range 27-35 CAG repeats) were identified, being 4 Caucasoids and 4 African-Brazilians. 
Table 1. Distribution of the number of CAG repeats in control subjects and in patients with HD, according to national or ethnic group.

\begin{tabular}{|c|c|c|c|c|}
\hline National or ethnic group & $\mathrm{N}^{\mathrm{o}}$ of subjects & & & References \\
\hline & \multicolumn{4}{|c|}{$\begin{array}{l}\text { Non-HD hromosomes } \\
\mathrm{N}^{\mathrm{o}} \text { of repeats }\end{array}$} \\
\hline Control subjects & & median & range & \\
\hline Brazilian Caucasoids & 50 & 17 & $7-33$ & This study \\
\hline Great Britain & 32 & 18.5 & $12-35$ & 25 \\
\hline Italy & 29 & 19 & $15-29$ & 25 \\
\hline Norway & 10 & 19.5 & $17-27$ & 25 \\
\hline Scotland & 20 & 19 & $14-25$ & 25 \\
\hline Sweden & 103 & 19 & $11-29$ & 25 \\
\hline South African & 112 & 17 & $11-29$ & 25 \\
\hline \multirow[t]{2}{*}{ African-Brazilians } & 42 & 17 & $13-30$ & This study \\
\hline & \multicolumn{4}{|c|}{$\begin{array}{l}\text { HD chromosomes } \\
\mathrm{N}^{\circ} \text { of repeats }\end{array}$} \\
\hline Patients with $H D$ & & median & range & \\
\hline Brazil & 44 & 45 & $39-88$ & This study \\
\hline Netherlands & 28 & 43 & $37-59$ & 25 \\
\hline England & 118 & 44 & $38-63$ & 25 \\
\hline France & 45 & 44 & $36-100$ & 25 \\
\hline Germany & 46 & 44 & $40-65$ & 25 \\
\hline Great Britain & 74 & 44 & $39-121$ & 25 \\
\hline Ireland & 43 & 42 & $39-52$ & 25 \\
\hline Italy & 52 & 44 & $39-54$ & 25 \\
\hline Norway & 23 & 46 & $39-71$ & 25 \\
\hline Russia & 22 & 41 & $37-47$ & 25 \\
\hline Scotland & 91 & 43 & $38-71$ & 25 \\
\hline Sweden & 103 & 43 & $38-88$ & 25 \\
\hline Canada & 35 & 45 & $36-75$ & 25 \\
\hline
\end{tabular}

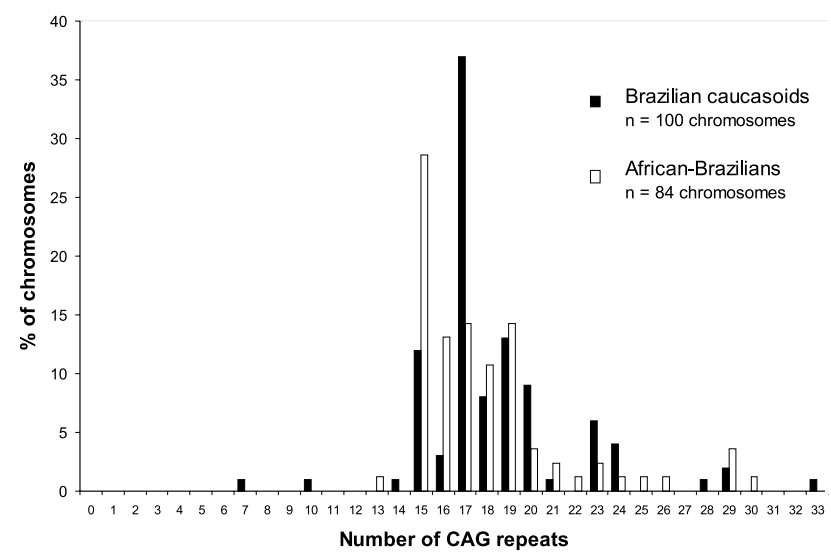

Fig 2. Number of $C A G$ repeats and \% of chromosomes in Caucasoids and AfricanBrazilians control subjects. 


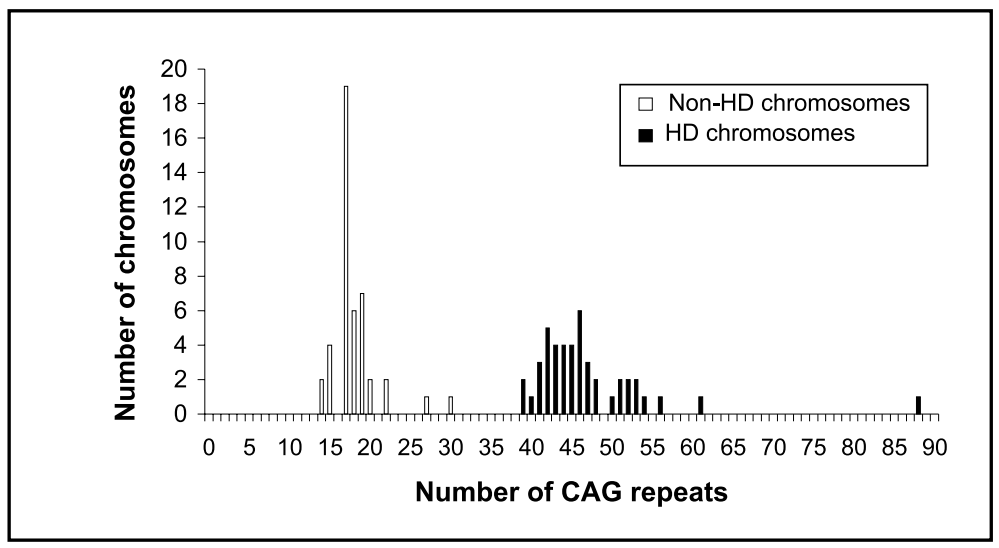

Fig 3. Number of CAG repeats x number of chromosomes in HD patients.

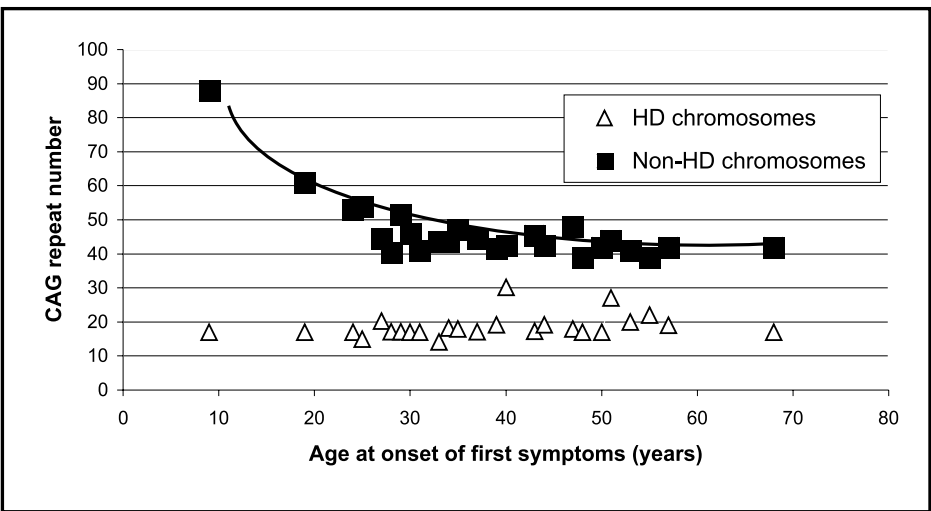

Fig 4. CAG repeat number $x$ age at onset of first symptoms in years, from affected subjects, showing inverse correlation in HD chromosomes. Some of the colored squares represent more than 2 patients.

\section{B) HD patients}

In all 44 HD patients the clinical diagnosis was confirmed by PCR analysis. Expanded CAG repeats ranged from 39 to 88 (mean 46.7 and median 45) and the normal CAG repeats from these patients ranged from 14 to 30 (mean 18 and median 17) (Fig 3).

Figure 4 shows the relationship between age at onset of first symptoms and the CAG repeat size in HD alleles in Brazilian affected subjects. An increase correlation for the age at onset of first symptoms and the number of CAG repeats was detected (Table 4).

\section{C) Families with $H D$}

DNA analysis was carried out in 40 individuals who were members of $6 \mathrm{HD}$ families (Fig 1 - Families A-F). Fifteen were HD patients (symptomatic), 13 were their relatives at $50 \%$ risk to develop this disease, 6 were their relatives at $25 \%$ risk to develop this disease, and 5 were married to a HD patient or to a person at 50\% risk to develop HD. Results showed an expanded CAG repeat in all $15 \mathrm{HD}$ patients tested and in 6 of their 13 first-degree relatives $(46,1 \%)$, previously at a $50 \%$ risk (Fig 4). The age of these asymptomatic family members who inherited one HD chromosome range from 21 to 50 years $($ median $=23 / 24$ years, $n=6)$. 
CAG analysis showed that the expanded repeat in families with HD ranged between 40 and $88($ mean $=50.7$ and median $=44 / 45)$, and normal chromosomes ranged between 15 and 25 (mean $=21.2$ and median $=18$ ).

The analysis of 4 of these 6 families resulted in molecular data from 6 HD father-child pairs and 4 HD mother-child pairs affected with HD (Tables 2 and 3).

Table 2. CAG repeat instability during 6 paternal and 4 maternal transmissions in 3 Brazilian HD families.

Transmission

\begin{tabular}{lcc} 
& Father-child $(\mathrm{n}=6)$ & Mother-child $(\mathrm{n}=4)$ \\
\hline Contract & 0 & 1 \\
Stable & 1 & 1 \\
Expansion & 5 & 2 \\
\hline
\end{tabular}

Table 3. Comparison of the CAG repeat instability during paternal transmission.

\begin{tabular}{ll}
\hline Transmission & Expansions/total \\
\hline$*$ HD families of Brazilian origin & $5 / 6$ \\
$* *$ Late onset causes from HD families of varied ethnic origin & $8 / 10$ \\
$* *$ HD families from various parts of Greece & $7 / 9$ \\
$* *$ HD families of varied ethnic origin & $8 / 10$ \\
$* *$ HD families of varied ethnic origin & $32 / 37$ \\
$* *$ HD families of Dutch origin & $10 / 16$ \\
$* *$ HD families of Scottish origin & $21 / 31$ \\
$* *$ HD families of Italian origin & $18 / 19$ \\
\hline
\end{tabular}

* This study; **In Tzagournissakis et al., $1995^{27}$.

Table 4. Median age at onset of first symptoms in HD patients.

\begin{tabular}{ccc}
\hline CAG repeat size & Median age at onset in years* & Age at onset in years** \\
\hline & $\mathrm{N}=886^{35}$ & $\mathrm{~N}=35$ \\
& & \\
49 & $66(72-29)$ & $55 / 48$ \\
40 & $59(61-56)$ & 28 \\
41 & $54(56-52)$ & $53 / 39 / 31$ \\
43 & $49(50-48)$ & $68 / 57 / 50 / 44 / 40$ \\
44 & $44(45-42)$ & $44 / 34 / 33$ \\
45 & $42(43-40)$ & $51 / 40 / 37 / 27$ \\
46 & $37(39-36)$ & $43 / 40$ \\
47 & $36(37-35)$ & $37 / 35$ \\
48 & $33(35-51)$ & $47 / 40$ \\
49 & $32(34-30)$ & 34 \\
50 & $28(32-25)$ & \\
\hline
\end{tabular}

*Age by which $50 \%$ of individuals will be affected ${ }^{27}$.**Due to our small sample size, we decided not to include the median ages, but the age of onset of each HD patient. 


\section{DISCUSSION}

\section{A) Control subjects}

Table 1 shows the distribution of the CAG repeats in the normal Brazilian sample. The frequency of intermediate alleles (meiotic unstable alleles) in the Brazilian Caucasoid general population is $4 \%$ (4/100) of chromosomes, therefore one in each 12 persons in the general Brazilian Caucasoid population may have an intermediate allele. This result is higher than the literature reported, where the frequency of intermediate alleles on normal Caucasoids chromosomes is $0.93 \%$, one in each 50 persons, as showed in the general Canadian population ${ }^{24}$. The frequency of intermediate alleles in the African-Brazilian general population is $4.7 \%$ (4/84) of chromosomes, therefore one in each 10 persons in the general African-Brazilian population may have an intermediate allele. This result is also higher than the ones reported in the literature, where no intermediate allele was found in normal chromosomes by Almqvist et al. ${ }^{20}$ and Squitieri et al. ${ }^{19}$, and 12/1595 were found by Kremer et al. ${ }^{25}$ in the South-African population. In the African-Brazilian control population the CAG repeat number mean (17.9) is higher than in African populations $\left(15.9^{20}\right.$ and $\left.16.2^{19}\right)$. Although this is in accordance to studies of African-Americans showing that they have a significant higher prevalence inherited alleles than Africans ${ }^{18}$, one has to be very careful comparing this means, considering the small sample analyzed. Even though, these two findings together suggest that the incidence of HD in the African-Brazilian population may be higher than in other African-descendant populations. One explanation could be the known higher rates of admixture between African-Brazilians and Brazilian Caucasoids that could have brought larger and more intermediate alleles to the AfricanBrazilian gene pool. Further studies are in progress to enlarge the normal population sample to confirm this initial finding.

\section{B) HD patients}

Among the affected patients no differences were found in CAG alleles frequencies from Brazilian subjects when compared to different national and ethnic groups (Table 1).

In the Brazilian HD patients studied, the lowest size associated with disease was 39 repeats and the highest 88 .

The patient which HD chromosome had 88 CAG repeats, manifested HD with 9 years old. The age of onset of first symptoms of this patient was not surprising when compared with other studies of juvenile onset forms of $\mathrm{HD}^{26}$, and strength the current knowledge that the higher the number of CAG repeats, the earlier will be the age of onset.

\section{C) Families with HD}

Although we studied a small sample of parents/sibling pairs, the molecular data obtained from $6 \mathrm{HD}$ father-child pairs and 4 mother-child pairs affected with HD suggest an increase of CAG repeat size on paternal but not always on maternal transmission (Table 2). The instability of the CAG repeat during paternal transmission in this sample is similar to that observed in most HD families studied worldwide (Table 3).

Two siblings, clinically followed by one of us (M.S.H.) (Family C in Figure 1), manifested HD with 5 and 11 years and their HD chromosomes have 88 and 69 CAG repeats respectively. The age of onset of first symptoms of these patients is now understandable, when compared with other studies showing correlation of large repeats with early age of onset and juvenile onset forms ${ }^{26}$. This two cases as well as the other 9 years old case described above with the HD patients, show that the general suggestion, to avoid testing asymptomatic minors for $\mathrm{HD}$, should take in account that the disease may manifest in individuals with less than 21 years old.

It is also interesting to note the case of identical twin sisters, clinically followed by one of us (G.L.) (Fig 1 D) which have the same CAG repeat numbers (22/62) on the HD gene, but slight 
different onset ages (17 and 20 years). They are monozygous twins, as proved by having both the same DNA genotypes in 9 different Short Tandem Repeats loci tested ${ }^{28}$. It seems by this case that there are also non-genetic factors influencing the age at onset of first symptoms of HD.

Due to absence of specific complementary tests to diagnose or to exclude HD PCR analysis of the CAG trinucleotide repeat number is the only definitive laboratorial diagnostic tool of $\mathrm{HD}$, useful not only for research but also when clinical diagnosis is not quite clear.

HD occurs with different prevalence rates in different parts of the world. It has been suggested that European immigration and genetic admixture could account for the variation in prevalence rates $^{1}$. The Brazilian population, with high rates of admixture between European descendants and African-Brazilians will be an interesting sample to learn more about the history, incidence and spread of HD.

Data generated from this type of studies may have significant implications for the knowledge of the incidence, diagnosis and prognosis in HD Brazilian patients. The aim of new therapies in HD is to slow or stop the progression of HD in affected persons and to delay or prevent onset in persons with CAG > 35 repeats. An appropriate design of clinical trials for increased-risk individuals will need to take into account the expected age at onset of first symptoms of HD for a particular person, in order to determine the potential efficacy of therapy ${ }^{26}$. Knowledge of the molecular basis of the disease in the Brazilian population should help families at risk and improve genetic counseling. As HD DNA test becomes routine in Brazil, all efforts must be provided so that psychiatric support is available for all persons that HD predictive testing is offered. Further studies are needed in the Brazilian population to asses the frequency of catastrophic events, such as suicide, suicide attempt and psychiatric hospitalization after receiving an HD DNA predictive test result, as it is now known that almost $1 \%$ of pre-symptomatic HD patients may have a catastrophic event after receiving the result of a predictive DNA-based test ${ }^{29}$.

Acknowledgments - We thank the physicians Remberto Rojas Balderrama, Heloísa Pacheco, Carla Heloisa Cabral Moro, Wanderley R. de Paula, Maria Betânia Pereira, Walter Taborda, Roberta Saba, Alexandre da Rocha Serra, Paulo E. M. Carrilho, Egberto Reis Barbosa, Eugênia R. Valadares, Lineu Cesar Werneck, Germano Hofman F., Alírio Peralta, Walter O. Arruda, Marcos Correia Sandmann, Marco Antônio Zota, Paolo Cava, Eduardo S. Hayashi, Dafne Dain Gandelman, Marcia Ferreira Miranda, Norberto Luiz Cabral, Luis Fernando G. da Silva, Eloy Cassa Jr., Paulo Roberto R. Moreira, Renato Gonçalves, Norberto D. Cabral, Cleverson M. Garcia, Marcia Aloes, Agnes Cristina F. Conte, for sending samples from HD patients. We also thank all HD patients and their families, for their collaboration making this study possible.

\section{REFERENCES}

1. Hayden MR. Huntington's chorea. London: Springer, 1981:59-75.

2. Harper PS. Huntington's disease. Major problems in neurology Vol. 22. London: WB Saunders, 1991;31-72.

3. Huntington's Disease Collaborative Research Group. A novel gene containing a trinucleotide repeat that is expanded an unstable on huntington's disease chromosomes. Cell 1993;72:971-983.

4. Lin B, Rommens JM, Graham RK, et al. Differential 3' polyadenylation of the Huntington disease gene results in two mRNA species with variable tissue expression. Hum Mol Genet 1993;2:1541-1545.

5. Pizzuti A, Friedman D, Caskey T. The myotonic dystrophy gene. Arch Neurol 1993;50:1173-1179.

6. Nagafuchi S, Yanagisawa H, Ohsaki E, Shirayama T, Tadokoro K. Structure and expression of the gene responsible for the triplet repeat disorder dentatorubral and pallidoluysian atrophy (DRPLA). Nat Genet 1994;8:177-182.

7. Orr H, Chung M, Banfi S, et al. Expansion of an unstable trinucleotide CAG-repeat in spinocerebellar ataxia type 1. Nat Genet 1993;4:221-226.

8. Kaimen-Maciel DR, Medeiros M, Climaco V, et al. Recessive bulbospinal muscular atrophy X-linked. Arq Neuropsiquiatr 1998;56:639-645.

9. LaSpada AR, Paulson H, Fishbeck K. Trinucleotide repeat expansion in neorological disease. Ann Neurol 1994;36:814-822.

10. American College of Medical Genetics/American Society of Human Genetics/Huntington Disease Genetic Testing Working Group (ACMG/ASHG Statement). Laboratory guidelines for Huntington disease genetic testing. Am J Hum Genet 1998;62:1243-1247.

11. McNeil SM, Novelletto A, Srinidhi J, et al. Reduced penetrance of the Huntington's disease mutation. Hum Mol Genet 1997;6:775-779.

12. Andrew SE, Goldberg YP, Theilmann J, Zeisler J, Hayden MR. A CCG repeat polymorphism adjacent to the CAG repeat in the Huntington's disease gene: implications for diagnostic accuracy and predictive testing. Hum Mol Genet 1994;3:65-67. 
13. Menkes JH. Huntington disease: finding the gene and after. Pediatr Neurol 1988;4:73-78.

14. Myers RH, Sax DS, Schoenfeld M, et al. Late onset of Huntington's Disease. J. Neurol. Neurosung Psychiatry 1985;48:530-534.

15. Telenius H, Almqvist E, Kremer B, et al. Somatic mosaicism in sperm is associated with intergenerational $(\mathrm{CAG})_{\mathrm{n}}$ changes in Huntington's disease. Mum Mol Genet 1995;4:189-195.

16. Kanazawa I. Prevalence rate of Huntington's chorea in Ibaraki prefectre. Ministry of Health and Welfare of Japan, 1983:151-156.

17. Hayden MR, MacGregor JM, Beighton PH. The prevalence of Huntington's chorea in South Africa. S Afr Med J 1980;58:193-196.

18. Wright HH, Still CN, Abramson RK. Huntington's disease in black kindreds in South Carolina. Arch Neurol 1981;38:412-414.

19. Squitieri F, Andrew SE, Goldberg YP, et al. DNA haplotype analyses of Huntington disease reveals clues to the origins and mechanisms of CAG expansion and reasons for geographic variations of prevalence. Hum Mol Genet 1994; 3:2103-2114.

20. Almqvist E, Spence N, Nichol K, et al. Ancestral differences in the distribution of the $\Delta 2642$ glutamic acid polymorphism is associated with varying CAG repeat lengths on normal chromosomes: insights into the genetic evolution of Huntington disease. Hum Mol Genet 1995;4:207-214.

21. John SWM, Weitzner G, Rozen R, Scriver CR. A rapid procedure for extracting genomic DNA from leukocytes. Nucleic Acids Res 1990;19:408.

22. Warner JP, Barron LH and Brock DJH. A new polymerase chain reaction (PCR) assay for the trinucleotide repeat that is unstable and expanded on Huntington's disease chromosomes. Mol. Cellular Probes 1993;7:235-239.

23. Muglia M, Leone O, Annesi G, et al. Nonisotonic method for accurate detection of (CAG) repeats causing Huntington disease. Clin Chem 1996;42:1601-1603.

24. Goldberg YP, McMurray CT, Zeisler J, et al. Increase instability of intermediate alleles in families with sporadic Huntington disease compared to similar sized intermediate alleles in the general population. Hum Mol Genet 1995;4:1911-1918.

25. Kremer HPH, Goldberg YP, Andrew SE, et al. A worldwide study of the Huntington's disease mutation: the sensitivity and specificity of measuring CAG repeats. N. Engl J Med 1994;330:1401-1406.

26. Brinkman RR, Mezei MM, Theilmann J, Almqvist E, Hayden MR. The likelihood of being affected with Huntington disease by a particular age, for a specific CAG size. Am. J Hum Genet 1997;60:1202-1210.

27. Tzagournissakis M, Fesdjian CO, Shashidharan P and Plaitakis A. Stability of the Huntington disease (CAG)n repeat in a late-onset form occurring on the Island of Creta. Hum Mol Genet 1995;4:2239-2243.

28. Schumm JW, Lins AM, Micka KA, et al. Automated fluorescent detection of STR multiplexes. Proceedings from the first European Symposium on Human Identification 1996:90-104.

29. Almqvist EW, Bloch M, Brinkman R, Craufurd D, Hayden MR. A worldwide assessment of the frequency of suicide, suicide attempts, or psychiatric hospitalization after predictive testing for Huntington disease. Am J Hum Genet 1999;64:12931304. 